\title{
AGRESIVITAS PELAPORAN KEUANGAN, AGRESIVITAS PAJAK, TATA KELOLA PERUSAHAAN DAN KEPEMILIKAN KELUARGA
}

\author{
Hanna dan Melinda Haryanto \\ Jurusan Akuntansi, Universitas Pelita Harapan \\ Email: hanna.wijaya@uph.edudan melinda.haryanto@uph.edu
}

\begin{abstract}
Tax revenue in Indonesia until 2014 contributed approximately $78 \%$ of total state revenue. This shows that the tax is important both for the country as a source of income, as well as for the company as a taxpayer. For companies, the tax to be paid is a burden for the company which will reduce net income. Based on earlier research, the management company will tend to act aggressive tax in financial reporting. Tax aggressiveness influenced also by the pattern of ownership of the company in which the role of corporate governance are expected to influence the direction of the management decision-making. The purpose of this study was to examine the effect of financial reporting aggressiveness, family ownership and corporate governance against tax aggressiveness. The samples are all companies listed on the Indonesian Stock Exchange (BEI) except finance, insurance and banks during the period 2010-2014. The method used is multiple regression method. The results showed that the audit committee and institutional ownership has a significant influence on the aggressiveness of the taxes while the aggressiveness of financial reporting and the ownership of the family did not have a significant effect on the aggressiveness of the tax.
\end{abstract}

Keywords: Aggressiveness Financial Reporting, Tax Aggressiveness, Family Ownership, Corporate Governance

\begin{abstract}
Abstrak: Penerimaan pajak di Indonesia sampai dengan tahun 2014 memberikan kontribusi sekitar 78\% dari total penerimaan negara. Hal ini menunjukkan bahwa pajak adalah penting baik untuk negara sebagai sumber pendapatan, maupun untuk perusahaan sebagai wajib pajak. Bagi perusahaan, pajak yang harus dibayarkan ini merupakan beban bagi perusahaan yang akan mengurangi laba bersih. Berdasarkan penelitian terdahulu, manajemen perusahaan akan cenderung melakukan tindakan pajak agresif dalam pelaporan keuangan. Agresivitas pajak dipengaruhi juga oleh pola kepemilikan perusahaan dimana peran tata kelola perusahaan diharapkan memberikan pengaruh dalam manajemen mengambil keputusan. Tujuan dari penelitian ini adalah untuk menguji pengaruh agresivitas pelaporan keuangan, kepemilikan keluarga dan tata kelola perusahaan terhadap agresivitas pajak. Sampel yang digunakan adalah semua perusahaan yang terdaftar pada Bursa Efek Indonesia (BEI) kecuali perusahaan keuangan, asuransi dan bank selama periode 2010-2014. Metode penelitian yang digunakan adalah metode regresi berganda. Dari hasil penelitian menunjukkan bahwa komite audit, kepemilikan institusional memiliki pengaruh signifikan terhadap agresivitas pajak sedangkan agresivitas pelaporan keuangan dan kepemilikan keluarga tidak memiliki pengaruh yang signifikan terhadap agresivitas pajak.
\end{abstract}

Kata Kunci: Agresivitas Pelaporan Keuangan, Agresivitas Pajak, Kepemilikan Keluarga, Tata Kelola Perusahaan. 


\section{PENDAHULUAN}

Penerimaan negara terdiri dari penerimaan perpajakan, penerimaan bukan pajak dan hibah. Dari 3 jenis penerimaan tersebut, penerimaan perpajakan menduduki proporsi yang cukup besar yaitu sekitar $68 \%$ - 79\% dari total penerimaan negara. Hal ini dapat kita lihat dari data pada www.bps.go.id sebagai berikut: Pada tahun 2007 terdapat penerimaan pajak sebesar Rp 490,988 milyar (69,53\% dari total penerimaan negara). Pada tahun 2008 terdapat penerimaan pajak sebesar Rp 658,701 milyar (67,26\% dari total penerimaan negara). Pada tahun 2009 terdapat penerimaan pajak sebesar Rp 619,922 milyar (73,18\% dari total penerimaan negara). Pada tahun 2010 terdapat penerimaan pajak sebesar Rp 723,307 milyar $(72,89 \%$ dari total penerimaan negara). Pada tahun 2011 terdapat penerimaan pajak sebesar Rp 873,874 milyar (72,5\% dari total penerimaan negara). Pada tahun 2012 terdapat penerimaan pajak sebesar Rp 980,518 milyar (73,59\% dari total penerimaan negara). Pada tahun 2013 terdapat penerimaan pajak sebesar Rp 1,148,365 milyar (76,68\% dari total penerimaan negara). Pada tahun 2014, dalam Rencana Anggaran Pendapatan dan Belanja Negara (RAPBN) pemerintah menganggarkan penerimaan pajak sebesar 1,310,219 milyar (78,87\% dari total penerimaan negara).

Dengan proporsi hampir mencapai $80 \%$ tersebut, maka pemerintah memberikan perhatian yang besar terhadap pajak. Disisi lain, pembayar pajak yang merupakan wajib pajak (dalam hal ini adalah perusahaan) memiliki anggapan bahwa pajak yang harus dibayarkan ini merupakan beban bagi perusahaan. Dengan bertambah besarnya beban pajak perusahaan maka akan mengurangi laba yang dapat dihasilkan oleh perusahaan. Dengan demikian menurut (Chen et al.,2010) pemilik perusahaan diduga lebih suka manajemen perusahaan melakukan tindakan pajak agresif. Frank et al (2009) menyatakan bahwa tindakan pajak agresif adalah suatu tindakan yang ditujukan untuk menurunkan laba kena pajak melalui perencanaan pajak baik menggunakan cara yang tergolong atau tidak tergolong tax evasion. Akan tetapi, dengan menurunkan laba, akan menimbulkan dampak disisi yang lain yaitu investor dan kreditorakan menilai perusahaan kurang bagus karena memiliki laba yang kecil. Perusahaan biasanya cenderung untuk meningkatkan laba karena motivasi untuk mendapatkan pinjaman atau investasi. Kecenderungan ini disebut sebagai agresivitas laporan keuangan.

Agresivitas pajak dipengaruhi pula oleh perusahaan keluarga atau perusahaan non keluarga. Dalam penelitian Chen et al. (2010), pada perusahaan keluarga memiliki tingkat agresivitas pajak yang lebih kecil dibandingkan perusahaan non keluarga. Ada beberapa faktor yang mempengaruhi hal tersebut yaitu diantaranya adalah reputasi perusahaan yang rusak bila terdapat masalah saat audit oleh kantor pajak, denda pajak yang lebih tinggi daripada yang seharusnya dibayar. Selain itu, pada perusahaan keluarga, masalah keagenan lebih kecil terjadi dibandingkan dengan perusahaan non keluarga, Pada perusahaan non keluarga, pemilik perusahaan tidak memegang sebagian besar posisi manajerial sehingga sering terjadi pengawasan yang kurang sempurna (masalah agensi).Menurut Desai dan Dharmapala (2007) dalam Sari dan Martani (2010) hal ini mendorong tindakan oportunis dari manajer sehingga dapat menimbulkan masalah corporate governance.

Dalam penelitian sebelumnya, mekanisme corporate governance yang diproksikan dengan ukuran dewan komisaris, ukuran komite audit, dan ukuran dewan direksi) berpengaruh terhadap agresivitas pajak (Winarsih, Prasetyono, Kusufi,2014). Demikian 
juga dalam penelitian Suyanto dan Supramono (2012), komisaris independen berpengaruh negatif terhadap agresivitas pajak. Penelitian Pohan (2009) tidak berhasil membuktikan kepemilikan institusional memiliki pengaruh terhadap agresivitas pajak.

Penelitian ini dilakukan dengan merujuk pada Ridha dan Martani (2014) . Yang menjadi perbedaan adalah penelitian ini menggunakan mekanisme tata kelola perusahaan dengan variabel komisaris independen, komite audit dan kepemilikan institusional. Selain itu periode yang digunakan berbeda yaitu penelitian ini menggunakan sampel perusahaan manufaktur dan non manufaktur (kecuali perusahaan keuangan, asuransi dan bank) dari tahun 2010-2014

\section{KAJIAN TEORI}

Agresivitas Pajak. Sesuai dengan Undang-Undang No. 28 Tahun 2007 pasal 1 ayat 1 mengenai Ketentuan Umum dan Tata Cara Perpajakan, pajak didefinisikan sebagai kontribusi wajib kepada negara yang terutang oleh orang pribadi atau badan yang bersifat memaksa berdasarkan Undang-Undang, dengan tidak mendapatkan imbalan secara langsung dan digunakan untuk keperluan negara bagi sebesar-besarnya kemakmuran rakyat. Sedangkan menurut Barata (2010), pajak merupakan iurang kepada Negara berdasarkan Undang-Undang yang dapat dipaksakan dengan tidak mendapat timbal jasa (kontraprestasi) yang langsung dapat ditunjukkan dan digunakan untuk membayar pengeluaran umum. Dari definisi tersebut dapat disimpulkan bahwa pajak merupakan suatu kewajiban yang bersifat memaksa berdasarkan Undang-Undang demi kepentingan umum.

Menurut Annisa dan Kurniasih (2012), dalam melakukan penghematan pajak secara legal dapat dilakukan melalui manajemen pajak. Meminimumkan kewajiban pajak dapat dilakukan dengan berbagai cara, baik yang masih memenuhi ketentuan perpajakan maupun yang melanggar peraturan perpajakan. Istilah yang sering digunakan adalah tax evasion dan tax avoidance. Sophar Lumbantoruan dalam bukunya akuntansi pajak (1996) memaparkan definisi terkait dua istilah tersebut. Tax evasion (penggelapan pajak) adalah penghindaran pajak dengan melanggar ketentuan peraturan perpajakan. Tax avoidance (penghindaran pajak) adalah penghindaran pajak dengan menuruti peraturan yang ada.

Balakrishnan et al. (2012) mendefinisikan agresivitas pajak sebagai manipulasi penghasilan kena pajak menjadi turun melalui perencanaan pajak yang mungkin atau mungkin juga tidak dianggap sebagai penipuan penggelapan pajak. Mengacu pada pengertian pajak agresif yang digunakan oleh Frank et al. (2009), pajak agresif didefinisikan sebagai suatu tindakan yang bertujuan untuk menurunkan laba kena pajak melalui perencanaan pajak baik menggunakan cara yang tergolong atau tidak tergolong tax evasion. Walau tidak semua tindakan yang dilakukan melanggar peraturan, namun semakin banyak celah yang digunakan perusahaan maka perusahaan tersebut dianggap semakin agresif.

Menurut Kamila dan Martani (2014), dalam dimensi perusahaan, pembayaran pajak dianggap sebagai transfer kekayaan dari perusahaan ke pemerintah. Beban pajak ini menjadi biaya yang sangat besar bagi perusahaan. Dalam rangka memaksimalkan nilai perusahaan, pemegang saham ingin meminimalkan pembayaran pajak perusahaan setelah dikurangi biaya-biaya pribadi melalui berbagai cara penghindaran atau penghematan 
pajak. Tindakan atau upaya meminimalkan beban pajak ini nantinya dapat menghasilkan pelaporan pajak yang agresif (Hanlon dan Slemrod, 2007).

Pembuat keputusan (manajer) akan memperhitungkan keuntungan dan kerugian tindakan pajak agresif yang dilakukannya. Ada tiga keuntungan tindakan pajak agresif yang akan dipaparkan di sini. (1) Keuntungan berupa penghematan pajak yang dibayarkan perusahaan kepada negara, sehingga porsi kas yang dinikmati pemilik/pemegang saham menjadi lebih besar. (2) Keuntungan (baik langsung atau tidak langsung) bagi manajer yang mendapatkan kompensasi dari pemilik/pemegang saham atas tindakan pajak agresif yang dilakukannya. (3) Keuntungan berupa kesempatan bagi manajer untuk melakukan rent extraction (Chen et al. 2010). Sedangkan kerugian dari tindakan pajak agresif antara lain adalah kemungkinan perusahaan mendapat sanksi/penalti dari fiskus pajak, dan turunnya harga saham perusahaan. Kemungkinan harga saham mengalami penurunan, dikarenakan pemegang saham lainnya mengetahui tindakan pajak agresif yang dijalankan manajer dilakukan dalam rangka rent extraction (Desai dan Dharmapala, 2006).

Agresivitas Pelaporan Keuangan. Komponen laporan yang menjadi pusat perhatian dan dijadikan acuan penilaian kinerja perusahaan adalah laba perusahaan. Informasi tentang laba (earnings) mempunyai peran sangat penting bagi pihak yang berkepentingan terhadap suatu perusahaan. Pihak internal dan eksternal perusahaan sering menggunakan laba sebagai dasar pengambilan keputusan seperti pemberian kompensasi dan pembagian bonus kepada manajer, pengukur prestasi atau kinerja manajemen, dan dasar penentuan besarnya pengenaan pajak. Oleh karena itu kualitas laba menjadi pusat perhatian bagi investor, kreditor, pembuat kebijakan akuntansi, dan pemerintah. Laba yang berkualitas adalah laba yang dapat mencerminkan kelanjutan laba (sustainable earnings) dimasa depan, yang ditentukan oleh komponen akrual dan aliran kasnya (Penman, 2001). Healy dan Wahlen (1999) menjelaskan bahwa earning management terjadi saat manajer menggunakan pendapat mereka dalam penyusunan laporan keuangan perusahaan dan mengelola transaksi yang terjadi sehingga mengubah laporan keuangan yang seharusnya, baik untuk menyesatkan stakeholder ataupun untuk mempengaruhi pengguna laporan keuangan lainnya yang bergantung pada angka-angka yang tercantum dalam laporan keuangan.

Kegiatan meningkatkan laba perusahaan melalui earning management, baik sesuai atau tidak sesuai dengan prinsip akuntansi yang berlaku dikenal dengan istilah agresivitas pelaporan keuangan (Frank et.al, 2009). Agresivitas pelaporan keuangan dapat tercermin melalui manajemen laba yang dilakukan perusahaan. Ewert dan Wagenhofer (2005) menyatakan bahwa salah satu cara yang dapat dilakukan perusahaan untuk manajemen laba adakah melalui penggunaan kebebasan atau diskresi untuk memilih metode dan estimasi akuntansi yang akan digunakan. Pengukuran manajemen laba atau tindakan pelaporan keuangan agresif sangat bermacam-macam. Namun, proksi yang sering digunakan adalah akrual diskresioner pada laporan keuangan perusahaan. Akrual diskresioner didapatkan sebagai residu dari regresi besaran pendapatan akrual (Jones, 1991). Model Jones ini kemudian banyak dikembangkan pada penelitian-penelitian selanjutnya, diantaranya Dechow et al. (1995), Kasznik (1999), Dechow et al. (2002), Kothari (2005).

Hubungan Pajak dan Pelaporan Keuangan. Perusahaan sebagai wajib pajak sering kali tidak mematuhi ketentuan perpajakan yang berlaku demi melakukan penghematan pajak. 
Terlebih lagi dengan adanya agency problem dan contractual problem yang mampu memicu dilakukannya penghematan pajak.

Agency problem merupakan masalah yang dihadapi perusahaan karena adanya benturan kepentingan antara pemilik atau pemegang saham dengan manajemen secara umum (Jensen dan Meckling, 1976). Masalah ini dapat terjadi karena tidak satunya visi antar kedua belah pihak tersebut sehingga masing-masing pihak berusaha untuk memaksimalkan keuntungannya masing-masing.

Menurut Kamila dan Martani (2014), hubungan antara pajak agresif dan pelaporan keuangan dapat bersifat resiprokal atau dua arah. Dengan kata lain manajemen pajak dapat mempengaruhi tindakan manajemen laba, begitu pula manajemen laba dapat mempengaruhi manajemen pajak yang dilakukan perusahaan. Hal ini dapat dilihat pada alasan dan motivasi dilakukannya manajemen laba dan manajemen pajak yang relatif sama. Manajemen pajak dikatakan mampu mempengaruhi manajemen laba karena salah satu upaya yang dilakukan dalam manajemen laba adalah pengendalian beban perusahaan, dimana salah satunya adalah pajak.

Kepemilikan Keluarga. Siregar et al., (2008) menemukan bahwa kepemilikan keluarga memiliki pengaruh yang signifikan pada jenis manajemen laba yang dipilih. Perusahaan dengan proporsi dari kepemilikan keluarga yang tinggi dan non-bisnis kelompok lebih cenderung untuk memilih manajemen laba efisien daripada jenis perusahaan lain. Kepemilikan saham di negara berkembang sebagian besar dikontrol oleh kepemilikan keluarga, termasuk perusahaan di Indonesia. Masalah keagenan pada perusahaan milik keluarga lebih sedikit karena memiliki sedikit konflik antara principal dan agent. Namun jika ada kepentingan minoritas di perusahaan milik keluarga, akan timbul masalah agensi lainnya, yaitu konflik kepentingan antara mayoritas (keluarga) dan kepemilikan minoritas. (Arifin, 2003). Fama dan Jensen (1983) menyatakan bahwa perusahaan dengan kepemilikan keluarga lebih efisien daripada perusahaan yang dimiliki publik karena biaya pengawasan yang dikeluarkan atau monitoring costnya lebih kecil.

Corporate Governance(Tata Kelola Perusahaan). Menurut Claessens dan Yurtoglu (2013), definisi tata kelola perusahaan sangat bervariasi dan cenderung dapat dikategorikan dalam dua kategori. Kategori pertama definisi tata kelola perusahaan menyangkut seperangkat pola perilaku: yaitu, perilaku yang sebenarnya dari perusahaan, dalam hal langkah-langkah seperti kinerja, efisiensi, pertumbuhan, struktur keuangan, dan perlakuan terhadap pemegang saham dan pemangku kepentingan lainnya. Kateogri kedua mengenai kerangka normatif: yaitu, aturan di mana perusahaan beroperasi-dengan aturan yang berasal dari sumber seperti sistem hukum, sistem peradilan, pasar keuangan, dan faktor (tenaga kerja) pasar.

Salah satu faktor penting yang menentukan tata kelola perusahaan dari perusahaan adalah independensi komite audit. Auditor memiliki tanggung jawab untuk memastikan jika posisi keuangan dan patrimonial diungkapkan secara andal oleh entitas (PeluccoGreco et al., 2014). Komite audit diukur dengan membandingan jumlah auditor independen dengan jumlah anggota komite audit. Kepemilikan institusional dapat digunakan sebagai cara untuk mengurangi konflik keagenan antara pemegang saham dan manajer. Secara rata-rata, investor institusi lebih baik memperoleh informasi dan kepemilikan institusional memiliki peran monitoring yang mendorong manajer untuk 
mengambil tindakan yang tidak akan merugikan perusahaan dalam jangka panjang termasuk kepemilikan oleh bank, perusahaan asuransi, dan reksadana, dana pensiun, reksa dana, dan bank investasi (Siregar et al., 2008). Herawaty (2008) dalam penelitiannya memasukkan peran monitoring yang dilakukan dewan komisaris independen sebagai salah satu mekanisme corporate governance yang diukur dengan persentase dewan komisaris independen dibanding total dewan komisaris yang ada.

\section{Hipotesis}

H1: Agresivitas pelaporan keuangan memiliki pengaruh terhadap agresivitas pajak

H2: Kepemilikan keluarga memiliki pengaruh terhadap agresivitas pajak.

H3: Tata kelola perusahaan memiliki pengaruh terhadap agresivitas pajak

\section{METODE}

Populasi yang digunakan dalam penelitian ini adalah seluruh perusahaan yang terdaftar pada Bursa Efek Indonesia (BEI) kecuali perusahaan keuangan, asuransi dan bank, selama periode 2010-2014. Metode yang digunakan dalam pengambilan sampel adalah purposive sampling berdasarkan kriteria sebagai berikut: (1) Terdaftar di BEI sebelum tahun 2010 dan sahamnya aktif diperdagangkan selama periode penelitian; (2) Menerbitkan laporan keuangan tahunan yang berakhir pada tanggal 31 Desember setiap tahunnya; (3) Laporan keuangan menggunakan mata uang Rupiah; (4) Memiliki data yang lengkap untuk setiap variabel yang diteliti.

Pengolahan data dengan menggunakan uji statistik deskriptif dan uji normalitas. Setelah itu diuji signifikansi dari masing-masing variabel. Untuk menguji pengaruh variabel independen terhadap variable dependen digunakan teknik analisis regresi berganda.Persamaan regresi dari model penelitian utama ini adalah sebagai berikut:

$$
\begin{aligned}
\mathrm{AP}= & \alpha+\beta_{1}(\mathrm{FO})+\beta_{2}(\mathrm{KI})+\beta_{3}(\mathrm{KA})+\beta_{4}(\mathrm{KINS})+\beta_{5}(\mathrm{APK})+\beta_{6}(\mathrm{LEV})+\beta 7(\mathrm{CR})+ \\
& \beta_{8}(\mathrm{UP})+\mathrm{e}
\end{aligned}
$$

Keterangan: $\alpha=$ Konstanta; $\beta=$ Koefisien; AP = Agresivitas Pajak; APK = Agresivitas Pelaporan Keuangan; $\mathrm{FO}=$ Kepemilikan Keluarga; KA $=$ Komite Audit; KINS $=$ Kepemilikan Institusional; $\mathrm{LEV}=$ Leverage $; \mathrm{CR}=$ Current Ratio $; \mathrm{UP}=$ Ukuran Perusahaan

Untuk mengukur besarnya agresivitas pelaporan keuangan digunakan proksi diskresi akrual yang dapat dihitung dengan menggunakan Modified-Jones Model yang dimodifikasi (Dechow et al 1995) dengan alasan bahwa model modifikasi jones merupakan model yang paling baik dalam mendeteksi manajemen laba dibandingkan model-model lainnya dan telah dipakai luas untuk menguji hipotesis mengenai manajemen laba (Alim, 2008).

$$
\text { TACCit }=\alpha_{0}+\alpha_{1}\left(\Delta \mathrm{REV}_{\mathrm{it}}-\Delta \mathrm{AR}_{\mathrm{it}}\right)+\alpha_{2} \mathrm{PPE}_{\mathrm{it}}+\varepsilon_{\mathrm{it}}
$$

\section{Keterangan:}

$\mathrm{TACC}_{\mathrm{it}}=$ total akrual perusahaan i pada tahun $\mathrm{t}$, yaitu selisih antara laba sebelum pos luar biasa dan operasi yang dihentikan dengan arus kas dari operasi

$\triangle \mathrm{REV}_{\mathrm{it}}=$ perubahan pendapatan perusahaan $\mathrm{i}$ tahun $\mathrm{t}$ dengan $\mathrm{t}-1$

$\Delta \mathrm{AR}_{\mathrm{it}} \quad=$ perubahan piutang dagang perusahaan $\mathrm{i}$ tahun $\mathrm{t}$ dengan $\mathrm{t}-1$ 
Beberapa penelitian sebelumnya menggunakan tarif pajak efektif sebagai proksi dari tingkat agresivitas pajak. Tarif pajak efektif yang rendah mencerminkan tingkat agresivitas pajak yang tinggi dan sebaliknya. Variabel tingkat agresivitas pajak dalam penelitian ini diukur dengan mengalikan tarif pajak efektif dengan -1 (Lanis dan Richardson, 2010):

$$
\text { Effective Tax Rate }=\frac{\text { Income Tax Expense }}{\text { Pretax Income }} \times-1
$$

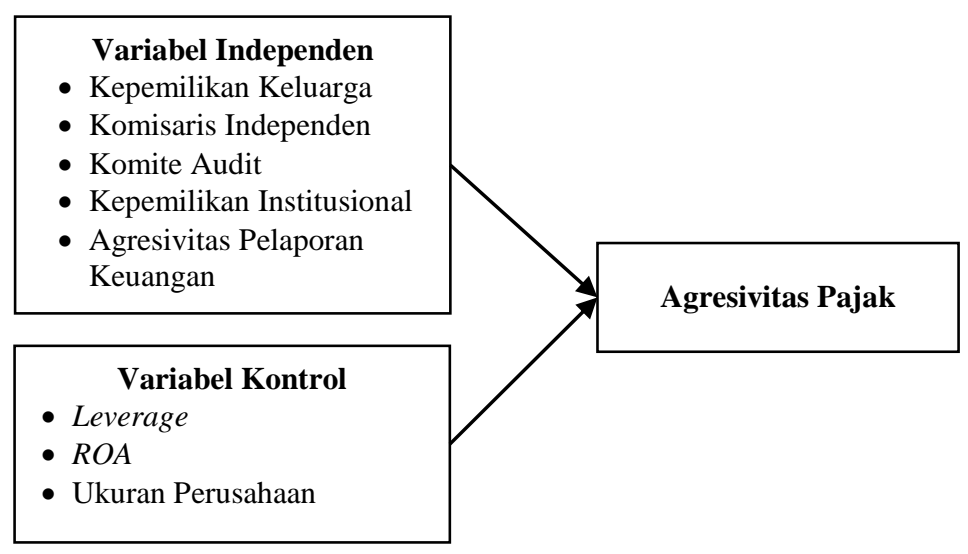

Gambar 1. Model Penelitian

Variabel-variabel dalam penelitian ini dihitung dengan rumus sebagai berikut: (1) Kepemilikan Keluarga (FO): Dummy variable, bernilai 1 jika proporsi kepemilikan keluarga $>50 \%$, dan bernilai 0 jika sebaliknya; (2) Komisaris Independen (KI): Jumlah lomisaris independen/total dewan komisaris yang ada; (3) Komite Audit (KA): Jumlah auditor independen/total komite audit yang ada; (4) Kepemilikan Institusional (KINS): Jumlah saham yang dimiliki institusi/total modal saham yang beredar; (5) Agresivitas Pelaporan Keuangan (APK); (6) Agresivitas Pajak (AP); (7) Leverage (LEV): Debt to equity ratio; (8) Return on Asset (ROA): Net Income / Total Assets; (9) Ukuran Perusahaan (UP): Natural log dari total aset.

\section{HASIL DAN PEMBAHASAN}

Berdasarkan kriteria pemilihan sampel yang dilakukan dengan metode purposive sampling, penelitian ini menggunakan jumlah sampel sebanyak 331 perusahaan. Jumlah total observasi penelitian adalah 1655 sampel(observasi dari tahun 2010-2014). Tabel 1 berikut adalah deskripsi pemilihan sampel: 
Tabel 1. Deskripsi Pemilihan Sampel

\begin{tabular}{lc}
\hline \multicolumn{1}{c}{ Kriteria Pemilihan Sampel } & Sampel \\
\hline Populasi perusahaan yang terdaftar pada Bursa Efek Indonesia & 507 \\
Tidak terdaftar di BEI dari tahun 2010 & $(104)$ \\
Bank dan lembaga keuangan lainnya serta perusahaan yang tidak memiliki data secara & $(72)$ \\
lengkap & \\
Jumlah perusahaan yang dijadikan sampel & 331 \\
Total data selama 5 tahun penelitian & 1655
\end{tabular}

Sumber: data olahan penulis

Tabel 2 menyajikan hasil statistik deskriptif variabel penelitian. Jumlah data yang digunakan dari tahun 2010 - 2014 adalah 1655sampel.Winsorization dipakai dalam $1 \%$. Extreme value $1 \%$ diganti dengan data di posisi $99 \%$.

Tabel 2. Statistik Deskriptif

\begin{tabular}{lclll}
\hline Variable & Mean & Std.Dev & Min & Max \\
\hline AP & 0,2000284 & 0,4574182 & $-2,417954$ & 2,515904 \\
APK & $-0,160628$ & 0,2005789 & $-0,89009$ & 0,84414 \\
Leverage & 0,7110332 & 1,349668 & 0 & 10,34787 \\
ROA & 0,0497183 & 0,1087606 & $-0,3375743$ & 0,4302465 \\
Size & 14,30317 & 1,813225 & 9,266989 & 18,19486 \\
FamOwner & 0,4 & 0,490046 & 0 & 1 \\
KomisarisI & 0,1831183 & 0,2118353 & 0 & 1 \\
KomiteAudit & 0,0807366 & 0,1454516 & 0 & 0,6666667 \\
KepemilikanIns & 0,2475536 & 0,3376047 & 0 & 0,9914032 \\
\hline
\end{tabular}

Sumber: Data olahan penulis

Agresivitas pajak (AP) memiliki rata-rata sebesar 0,20 dengan standar deviasi 0,46 dan nilai minimum $-2,42$ serta nilai maksimum 2,52. Hal ini menunjukkan bahwa rata-rata perusahaan membayar pajak sebesar 20\% dari laba sebelum pajak. Agresivitas Pelaporan Keuangan (APK) memiliki rata-rata sebesar -0,16 dengan standar deviasi 0.20 dan nilai minimum -0,89 serta nilai maksimum 0,84. Hal ini menunjukkan bahwa rata-rata sampel perusahaan secara umum melakukan manajemen laba dengan melakukan kebijakan akrual yang menurunkan laba sebesar $16 \%$ dari total asset tahun $\mathrm{t}-1$.

Leverage memiliki rata-rata sebesar 0,71 dengan standar deviasi 1,35 dan nilai minimum 0 serta nilai maksimum 10,35. Hal ini menunjukkan bahwa rata-rata sampel perusahaan memiliki Rp 0,71 utang untuk setiap $\mathrm{Rp} 1$ modal yang dimiliki perusahaan.Return on Assets (ROA) memiliki rata-rata sebesar 0,05 dengan standar deviasi 0,11 dan nilai minimum -0,34 serta nilai maksimum 0,43. Hal ini menunjukkan bahwa rata-rata sampel memiliki tingkat pengembalian sebesar 5\% dibandingkan dengan asset lancar yang dimilikinya. Ukuran perusahaan (Size) memiliki rata-rata sebesar 14,30 dengan standar deviasi 1,81 dan nilai minimum 9,27 serta nilai maksimum 18,19. Hal ini menunjukkan bahwa rata-rata sampel memiliki ukuran perusahaan sebesar 14,3.

Family ownership memiliki rata-rata sebesar 0,4 dengan standar deviasi 0,49 dan nilai minimum 0 serta nilai maksimum 1 . Hal ini menunjukkan bahwa rata-rata sampel merupakan perusahaan dengan kepemilikan keluarga sebesar 0,4 atau $40 \%$ dari total 
sampel. Komisaris Independen memiliki rata-rata sebesar 0,18 dengan standar deviasi 0,21 dan nilai minimum 0 serta nilai maksimum 1 . Hal ini menunjukkan bahwa rata-rata sampel memiliki komisaris independen sebesar 0,18 dari total sampel.

Komite audit memiliki rata-rata sebesar 0,08 dengan standar deviasi 0,14 dan nilai minimum 0 serta nilai maksimum 0,67. Hal ini menunjukkan bahwa rata-rata sampel memiliki jumlah auditor independen dibandingkan dengan total jumlah komite audit sebesar 0,08 dari total sampel. Kepemilikan Institusional memiliki rata-rata sebesar 0,25 dengan standar deviasi 0,34 dan nilai minimum 0 serta nilai maksimum 0,99 . Hal ini menunjukkan bahwa rata-rata sampel perusahaan dengan modal yang dimiliki oleh institusi sebesar $25 \%$

Pemilihan model panel data. Hipotesis dalam penelitian ini diuji dengan menggunakan regresi panel data. Pada model panel data, akan diuji apakah menggunakanfixed effect atau random effect menggunakan Hausman test. Model fixed effect mengasumsikan independen variabel berkorelasi dengan error-nya sedangkan random effect sebaliknya.Dari pengujian tersebut diperoleh hasil sebagai berikut:

Prob $>$ chi $2=0,0231$ sehingga model yang cocok digunakan adalah dengan fixed effect.

\section{Uji Diagnosa}

1. Uji cross dependency. Uji ini menggunakan pesaran's test of cross sectional independence. Diperoleh hasil Pesaran's test of cross sectional independence $=19,405 ; \operatorname{Pr}$ $=0,0000 ;$ Average absolute value of the off-diagonal elements $=0,540$

Dari hasil tersebut menunjukkan bahwa didalam data yang dijadikan sampel terdapat cross dependency.

2. Uji Heteroscedasticity. Dengan menggunakan modified wald test pada model fixed effect, diperoleh hasil chi2 $(331)=6.2 \mathrm{e}+08$ dengan prob $>$ chi $2=0.0000$. Dari hasil tersebut menunjukkan adanya heterokedastisitas.

3. Uji Autocorrelation. Uji autokorelasi dilakukan dengan menggunakan Wooldridge test dengan hasil Prob $>\mathrm{F}=0.0000$. Karena hasil $\mathrm{F}<0.005$ maka terdapat autokorelasi. Untuk memperbaiki masalah cross dependency, heteroscedasticity danautocorrelation maka digunakan xtscc dengan menggunakan regresi Driscoll Kraay standard errors.

Pengujian Hipotesis. Berikut ini adalah hasil pengujian regresi dimana hipotesis diuji dengan menggunakan Fixed Effect Model dengan regresi Driscoll Kraay standard errors. Hasil pengujian dapat dilihat pada Tabel 3.

Pada Tabel 3, koefisien regresi Family ownership terhadap agresivitas pajak menunjukkan arah negatif sebesar 0,0036 . Nilai $\mathrm{p}$ value dari family ownership terhadap agresivitas pajak $(0,883)$ berada diatas signifikan $\alpha=5 \%$, menunjukkan bahwa family ownership tidak berpengaruh signifikan terhadap agresivitas pajak yang berarti perusahaan yang dimiliki olah keluarga ataupun non keluarga, tidak mempengaruhi pembayaran pajak oleh perusahaan. Oleh karena itu, hipotesis 1 ditolak.

Koefisien regresi komisaris independen terhadap agresivitas pajak menunjukkan arah negative sebesar 0,1495 . Nilai $p$ value dari komisaris independen terhadap agresivitas pajak $(0,054)$ berada diatas signifikan $\alpha=5 \%$, menunjukkan bahwa komisaris independen tidak berpengaruh signifikan terhadap agresivitas pajak. Hal ini menunjukkan bahwa dewan komisaris independen yang seharusnya menjalankan perannya dalam memantau, 
mendisiplinkan dan mempengaruhi manajer, tidakmelakukan fungsi pengawasan secara baik terhadapmanajemen.

Tabel 3. Hasil Regresi

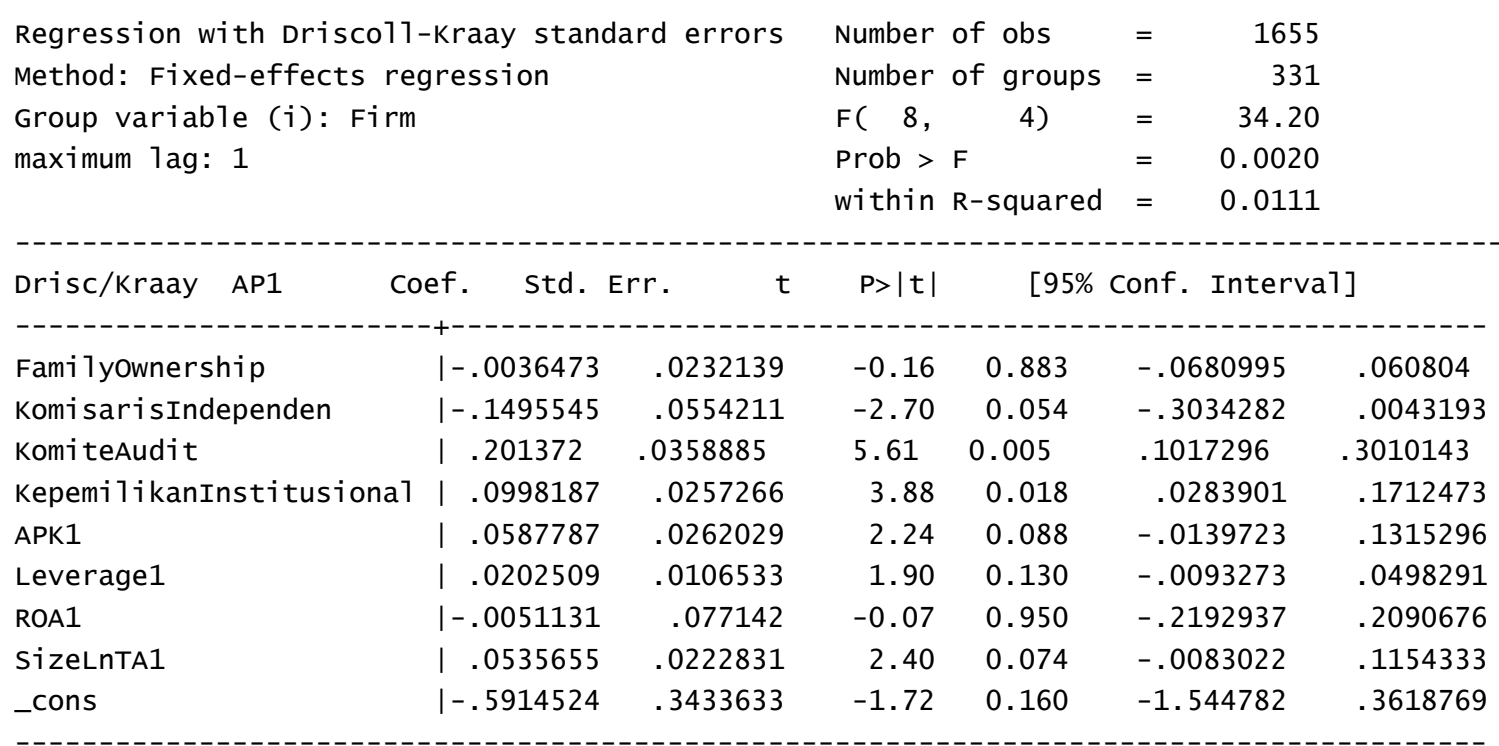

Sumber: Data olahan penulis dengan menggunakan stata

Koefisien regresi komite audit terhadap agresivitas pajak menunjukkan arah positif sebesar 0,2013 . Nilai $p$ value dari komite audit terhadap agresivitas pajak $(0,005)$ berada dibawah signifikan $\alpha=5 \%$, menunjukkan bahwa komite audit berpengaruh signifikan terhadap agresivitas pajak. Hal ini menunjukkan bahwa keberadaan komite audit berjalan sesuai fungsinya untuk meningkatkan keandalan pelaporan keuangan perusahaan.

Koefisien regresi kepemilikan institusional terhadap agresivitas pajak menunjukkan arah positive sebesar 0,998. Nilai $\mathrm{p}$ value dari kepemilikan institusional terhadap agresivitas pajak $(0,018)$ berada dibawah signifikan $\alpha=5 \%$, menunjukkan bahwa kepemilikan institusional berpengaruh signifikan terhadap agresivitas pajak. Hasil penelitian ini sesuai dengan penelitian yang dilakukan oleh Khuranadan Moser (2009) dimana dalam penelitiannya, Khurana dan Moser (2009) menemukan bahwa besar kecilnya konsentrasi kepemilikan institusional maka akan mempengaruhi kebijakan pajak agresif oleh perusahaan, dan semakin besarnya konsentrasi short-term shareholder institusional akan meningkatkan kebijakan pajak agresif, tetapi semakin besar konsentrasi kepemilikan long-term share holder maka akan semakin mengurangi tindakan kebijakan pajak yang agresif.

Koefisien regresi agresivitas pelaporan keuangan terhadap agresivitas pajak menunjukkan arah positive sebesar 0,058. Nilai $\mathrm{p}$ value dari agresivitas pelaporan keuangan terhadap agresivitas pajak $(0,0088)$ berada diatas signifikan $\alpha=5 \%$, menunjukkan bahwa agresivitas pelaporan keuangan tidak berpengaruh signifikan terhadap agresivitas pajak. Hal ini mengindikasikan manajemen pajak yang dilakukan perusahaan tidak dipengaruhi oleh tindakan manajemen laba. Pengaruh yang tidak signifikan ini diduga karena pada penelitian ini tidak dibedakan perusahaan manufaktur 
dan nonmanufaktur dimana terdapat pola kegiatan ekonomi dan karakteristik yang berbeda antara perusahaan nonmanufaktur dan manufaktur dalam operasionalnya. Sehingga manajemen juga akan mengelola labanya secara berbeda.

Koefisien regresi leverage terhadap agresivitas pajak menunjukkan arah positif sebesar 0,2025 . Nilai $p$ value dari leverage terhadap agresivitas pajak $(0,130)$ berada diatas signifikan $\alpha=5 \%$, menunjukkan bahwa leverage tidak berpengaruh signifikan terhadap agresivitas pajak.

Koefisien regresi ROA terhadap agresivitas pajak menunjukkan arah negatif sebesar 0,051 . Nilai $\mathrm{p}$ value dari ROA terhadap agresivitas pajak $(0,95)$ berada diatas signifikan $\alpha$ $=5 \%$, menunjukkan bahwa ROA tidak berpengaruh signifikan terhadap agresivitas pajak.

Koefisien regresi ukuran perusahaan (size) terhadap agresivitas pajak menunjukkan arah positif sebesar 0,0535 . Nilai $p$ value dari size terhadap agresivitas pajak $(0,074)$ berada diatas signifikan $\alpha=5 \%$, menunjukkan bahwa size tidak berpengaruh signifikan terhadap agresivitas pajak.

\section{PENUTUP}

Penelitian ini mencoba memberikan bukti empiris akan pengaruh agresivitas pelaporan keuangan, tata kelola perusahaan dan kepemilikan keluarga terhadap agresivitas pajak. Dalam mengukur tata kelola perusahaan, digunakan variabel komisaris independen, komite audit dan kepemilikan institusional. Berdasarkan hasil pengolahan data selama periode tahun 2010-2014 yaitu sebanyak 1655 sampel, maka didapatkan hasil bahwa kepemilikan keluarga, komisaris independen, agresivitas pelaporan keuangan, leverage, ROA dan ukuran perusahaan tidak berpengaruh signifikan terhadap agresivitas pajak. Sedangkan komite audit dan kepemilikan institusional memiliki pengaruh yang signifikasi terhadap agresivitas pajak dengan menggunakan tingkat signifikasi $\alpha=5 \%$. Penelitian ini belum mampu membuktikan keseluruhan pengaruh sesuai hipotesis yang dirumuskan namun dari hasil penelitian ini dapat disimpulkan bahwa tata kelola perusahaan yang diproksikan dengan komite audit dan kepemilikan insitusional telah menjalankan fungsinya kepada manajemen perusahaan dalam melakukan agresivitas pajaknya.

Untuk penelitian selanjutnya, disarankan menggunakan proksi lain dalam pengukuran agresivitas pajak seperti mempertimbangkan book-tax difference dan menggunakan pengukuran agresivitas pelaporan keuangan dengan pendekatan lainnya. Peneliti selanjutnya juga disarankan untuk membedakan penelitian berdasarkan industri untuk mendapatkan hasil yang lebih dapat digeneralisir.

\section{DAFTAR RUJUKAN}

Alim, S. (2009) "Manajemen Laba dengan Motivasi pajak pada Badan Usaha Manufaktur di Indonesia". Jurnal Keuangan dan Perbankan. 13 (3): 444-461.

Annisa, N. A. dan Kurniasih L. (2012) "Pengaruh Corporate Governance Terhadap Tax Avoidance". Jurnal Akuntansi dan Auditing, 8 (2): 123-136.

Arifin, Z. (2003) Masalah Agensi dan Mekanisme Kontrol pada Perusahaan dengan Struktur Kepemilikan Terkonsentrasi yang Dikontrol Keluarga: Bukti dari 
Perusahaan Publik di Indonesia. Unpublished Dissertation, FEUI Graduate Program in Management.

Barata, Atep Adya. (2010) Ketentuan Umum dan Tata Cara Perpajakan: Pengetahuan Dasar Perpajakan. Jakarta: Artha Bakti Nagara.

Chen, S., Chen, X., Cheng, Q dan Shevlin, T. (2010) "Are family firms more tax aggressive than non-family firms?", Journal of Financial Economics, Vol. 95: 4161.

Claessens \& Yurtoglu. (2013) "Corporate governance in emerging markets: A survey". Emerging Market Review Vol. 15: 1-33.

Desai, M.A. \& Dharmapala, D. (2006) "Corporate tax avoidance and high-powered incentives". Journal of Financial Economics, Vol. 79:145-179.

Ewert, R., dan A. Wagenhofer. (2005) "Economic Effects of Tightening Accounting Standards to Restrict Earnings Management". The Accounting Review, 80 (4): 1-24.

Fama, E., \& Jensen, M. (1983) "Separation of ownership and control". Journal of Law and Economics, Vol. 26: 301-325.

Frank, M., Lynch, L., dan Rego, S. (2009) "Tax reporting aggressiveness and its relation to aggressive financial reporting". The Accounting Review, Vol. 84: 467-496.

Hanlon, M. dan Slemrod, J. (2009) "What does tax aggressive signal? Evidence from stock price reactions to news about tax shelter environment". Journal of Public Economics.

Healy, P.M. and J.M. Wahlen. (1999) "A Review of The Earnings Management Literature and Its Implications For Standard Setting”. Accounting Horizons. 13 (4): 365-383.

Herawaty, Vinola. (2008) "Peran Praktek Corporate Governance Sebagai Moderating Variable Dari Pengaruh Manajemen laba Terhadap Nilai Perusahaan". Jurnal Akuntansi dan Keuangan, 10 (2): 97-108.

Jones, J. J. (1991) "Earnings management during import relief investigation". Journal of Accounting Research, Vol. 29: 193-228.

Jensen, Michael C. \& W.H. Meckling. (1976) "Theory of The Firm: Managerial Behavior, Agency Cost and Ownership Structure”. Journal of Financial Economics 3.

Kamila, P.A. dan Martani D. (2014) Analisis Hubungan Agresivitas Pelaporan Keuangan dan Agresivitas Pajak. Simposium Nasional Akuntansi VII, September 2014, pp. 125.

Khurana, I. K. dan W. J. Moser. (2009) Institutional Ownership and Tax Aggressiveness. www.ssrn.com

Lumbantoruan, Sophar. (1996) Akuntansi Pajak. Edisi revisi, Jakarta: PT Gramedia Widiasarana Indonesia.

Pelucio-Grecco, M. C., C.M. S. Geron, G. B. Crecco, \& J. P. C. Lima (2014) The Effect of IFRS on Earnings Management in Brazilian Non-Financial Public Companism. Emerging Markets Review, Vol. 21: 42-66.

Penman, Stephen H. (2001) Financial Statement Analysis and Security Valuation. Singapore: Mc Graw Hill.

Pohan,Hotman T. (2009) "Analisis pengaruh kepemilikan institusi, rasio tobin q, akrual pilihan, tarif efektif pajak, dan biaya pajak ditunda terhadap penghindaran pajak pada perusahaan public". Jurnal informasi, perpajakan, akuntansi dan keuangan public vol. 4 (2): $113-135$ 
Ridha, Muhammad \& Martani,Dwi (2014) Analisis terhadap Agresivitas Pajak, Agresivitas Pelaporan Keuangan, Kepemilikan Keluarga, dan Tata Kelola Perusahaan di Indonesia. Simposium Nasional Akuntansi XVII, 24-27 Sept 2014

Sari, Dewi Kartika \& Martani, Dewi (2010) Karakteristik Kepemilikan Perusahaan, Corporate Governance, dan Tindakan Pajak Agresif. Simposium Nasional Akuntansi XIII.

Siregar, S.V., \& S. Utama. (2008) "Types of Earnings Management and The Effect of Ownership Structure, Firm Size, and Corporate-Governance Practices: Evidence from Indonesia". The International Journal of Accounting, 43: 1-27.

Suyanto,Krisnata Dwi \& Supramono (2012) "Likuiditas, Leverage, Komisaris Independen, dan Manajemen Laba terhadap Agresivitas Pajak Perusahaan”. Jurnal Keuangan dan Perbankan, 16 (2):167-177

Undang-Undang No. 28 Tahun (2007) Ketentuan Umum dan Tata Cara Perpajakan. Available from http://www.dpr.go.id/dokjdih/document/uu/UU_2007_28.pdf; Internet; Accessed 7 September 2015.

Winarsih,Prasetyono \& Kusufi (2014) Pengaruh Good Corporate Governance dan Corporate Sosial Responsibility Terhadap Tindakan Pajak Agresif (Studi pada Perusahaan Manufaktur yang Listing di BEI Tahun 2009-2012). Simposium Nasional Akuntansi VII, September 2014. 